\title{
Protein Kinase A Activation Increases Sodium Current Magnitude in the Electric Organ of Sternopygus
}

\author{
Lynne McAnelly and Harold H. Zakon \\ Department of Zoology and Center for Developmental Biology, The University of Texas at Austin, Austin, Texas 78712
}

The inactivation kinetics of the $\mathrm{Na}^{+}$current of the weakly electric fish Sternopygus are modified by treatment with androgens. To determine whether phosphorylation could play a role in this effect, we examined whether activation of protein kinase A by 8 bromo cyclic AMP (8 Br cAMP) altered voltagedependent properties of the current. Using a two-electrode voltage-clamp procedure, we found no effect of $8 \mathrm{Br}$ cAMP on inactivation kinetics or other voltage-dependent properties of the $\mathrm{Na}^{+}$current of the electrocytes. However, treatment with 8 $\mathrm{Br}$ cAMP did produce a dose-dependent increase in the $\mathrm{Na}^{+}$ current compared with saline controls: $17.6 \%$ at $100 \mu \mathrm{M}, 42.4 \%$ at $1 \mathrm{~mm}$, and $43.1 \%$ at $5 \mathrm{~mm}$. This effect was blocked by $30 \mu \mathrm{M}$ $\mathrm{H} 89$, a PKA inhibitor, indicating that the observed effect was attributable to $8 \mathrm{Br}$ cAMP activation of PKA. We conclude that androgen-induced changes in $\mathrm{Na}^{+}$current inactivation are not mediated by PKA and suggest that PKA-mediated increases in $\mathrm{Na}^{+}$current underlie increases in the amplitude of the electric organ discharge observed in social interactions or with changes in water conductance.

Key words: protein kinase $A$; sodium channel; phosphorylation; cyclic adenosine monophosphate; $8 \mathrm{Br}$ cAMP; electric fish; electric organ
Voltage-dependent $\mathrm{Na}^{+}$channels are responsible for the depolarization of nerve and muscle cells that initiates the action potential (AP). Despite the all or none nature of the AP, characteristics such as duration, refractory period, or amplitude may vary, depending, for example, on cell type or developmental stage. Although $\mathrm{K}^{+}$channel diversity is often responsible for shaping the unique characteristics of APs in specific cell types, it has become increasingly clear that diversity in and modulation of $\mathrm{Na}^{+}$channels also can underlie AP variation.

This can be seen clearly in the AP of the electric organ (EO) of the weakly electric fish Sternopygus. Like other electric fish, Sternopygus generates an electric field from the summed APs of the electrocytes comprising its EO (Bennett, 1961, 1971), which is used in electrolocation and in social communication (Bullock and Heiligenberg, 1986). Within the species-specific range of EO discharge (EOD) frequencies $(50-200 \mathrm{~Hz})$, individual Sternopygus display an individually distinct and sexually dimorphic EOD, with sexually mature males displaying lower EOD frequencies (50-90 $\mathrm{Hz})$ and females discharging at higher frequencies $(110-200 \mathrm{~Hz})$ (Hopkins, 1972, 1974; Meyer, 1983; Zakon et al., 1991).

The EOD waveform is determined both by the firing frequency of the medullary pacemaker nucleus, as well as the AP duration of the electrocytes. AP duration varies with EOD frequency in a graded manner such that electrocytes in fish that generate the lowest frequency EODs have the longest duration APs, whereas electrocytes from fish with high-frequency EODs make shortduration APs (Mills and Zakon, 1987, 1991). The fast inactivation kinetics of the $\mathrm{Na}^{+}$current vary systematically with AP duration, and this variation is the basis for the individual differences in AP duration (Ferrari et al., 1995). Androgen strongly modulates EO

\footnotetext{
Received Feb. 1, 1996; revised April 8, 1996; accepted April 23, 1996.

This work was funded by National Institutes of Health Grant RO1 NS25513 (H.Z.) and Office of Naval Research Grant NOOD14-91-J-1178 (H.Z.)

Correspondence should be addressed to Dr. Lynne McAnelly, Department of Zoology, The University of Texas at Austin, Austin, TX 78712.

Copyright (C) 1996 Society for Neuroscience $0270-6474 / 96 / 164383-06 \$ 05.00 / 0$
}

output; dihydrotestosterone (DHT) implants lower the EOD frequency, broaden the AP duration (Mills and Zakon, 1987, 1991), and slow the $\mathrm{Na}^{+}$current inactivation time constant (Ferrari et al., 1995).

Several mechanisms could give rise to individual variations in and androgen-dependent modulation of $\mathrm{Na}^{+}$channel kinetics. Different isoforms of the $\mathrm{Na}^{+}$channel have been described (Hille, 1992), which may vary kinetically (Kallen et al., 1990; Elliott and Elliott, 1993; Ogata and Tatebayashi, 1993; Rizzo et al., 1994). In some tissues, association of $\beta$ subunits with the main $(\alpha)$ subunit influences channel kinetics (Isom et al., 1992). Finally, posttranslational modification of $\mathrm{Na}^{+}$channels by phosphorylation can regulate $\mathrm{Na}^{+}$channel function (Numann et al., 1991; Li et al., 1993).

In this study, we investigated the role of phosphorylation via activation of protein kinase $\mathrm{A}$ (PKA) on $\mathrm{Na}^{+}$channel kinetics and amplitude. We focused on PKA because work on the phylogenetically related eel Electrophorus electricus indicates that PKA, but not protein kinase $\mathrm{C}$ (PKC), phosphorylates the eel $\mathrm{EO} \mathrm{Na}^{+}$ channel, resulting in physiologically significant modulation of the channel (Emerick and Agnew, 1989; Emerick et al., 1993).

\section{MATERIALS AND METHODS}

Animals. Sternopygus macrurus were obtained commercially and maintained in aquaria in controlled temperature chambers. Immediately before electrocyte recording, external recordings of the whole animal's EOD frequency were made in the home aquarium.

Tissue preparation. The Sternopygus EO preparation has been described previously (Ferrari and Zakon, 1993; Ferrari et al., 1995). A small $(1.5-2.0 \mathrm{~cm})$ section of the tail was removed and placed in a simplified Hickman's saline containing (in $\mathrm{mM}$ ): $114 \mathrm{NaCl}, 2 \mathrm{KCl}, 4 \mathrm{CaCl}_{2}, 2 \mathrm{MgCl}_{2}$, 5 HEPES, 3 glucose, $\mathrm{pH}=7.2$. Curare ( $d$-tubocurarine chloride, $5 \mathrm{mg} / \mathrm{l}$, Sigma, St. Louis, MO) was added to prevent spontaneous contractions of the small muscle fibers in the tail. The skin was removed to expose the electrocytes for intracellular recording, and the tissue was pinned into a SYLGARD recording chamber. Recordings were made at room temperature $\left(23 \pm 1{ }^{\circ} \mathrm{C}\right)$.

Voltage clamp. The voltage-clamp procedure for Sternopygus has been described previously (Ferrari and Zakon, 1993; Ferrari et al., 1995). Two 
microelectrodes were used to voltage-clamp the electrocytes (Axoclamp 2-A amplifier, TL-1 DMA interface and pClamp software, Axon Instruments, Foster City, CA; Lab Master DMA boards, Scientific Solutions, Solon, OH; and Dell 325D computer, Austin, TX). Microelectrodes were pulled from thin-wall filament glass (No. 6160, A-M Systems, Everett, WA) on a Flaming-Brown model P-80/PC and had resistances of $0.5-2.5$ $\mathrm{M} \Omega$ when filled with $3 \mathrm{M} \mathrm{KCl}$. A grounded shield was placed between the two electrodes and lowered as close to the bath surface as possible. The saline level was also adjusted so as to just cover the tissue surface, which, in conjunction with the grounded shield, served to reduce coupling capacitance between the electrodes. The two microelectrodes were placed in the posterior, active end of superficial electrocytes. The ground electrode was a chlorided silver wire inserted into a plastic tube filled with $3 \%$ agar in $3 \mathrm{M} \mathrm{KCl}$.

As described previously (Ferrari and Zakon, 1993), to achieve a good space clamp, we blocked the electrocyte's chloride leakage by replacing the $\mathrm{NaCl}$ with $\mathrm{Na}^{+}$methyl sulfate in the recording saline containing (in mM): $110 \mathrm{Na}^{+}$methyl sulfate, $2 \mathrm{KCl}, 4 \mathrm{CaCl}_{2}, 1 \mathrm{MgCl}_{2}, 5$ HEPES, 3 glucose, and $5 \mathrm{mg} / \mathrm{l}$ curare, $\mathrm{pH}=7.2$. In addition, $40 \mathrm{~mm}$ tetraethylammonium and $2 \mathrm{~mm} \mathrm{CsCl}_{2}$ were added to block the electrocyte $\mathrm{K}^{+}$ currents. The $\mathrm{Na}^{+}$current was isolated for analysis by subtracting the linear leakage from the $\mathrm{Na}^{+}$current by using a depolarizing prepulse to inactivate the $\mathrm{Na}^{+}$current after $\mathrm{K}^{+}$currents were blocked pharmacologically. Criteria for a well clamped $\mathrm{Na}^{+}$current were as described (Ferrari et al., 1995).

Pulse protocols to determine current activation, fast inactivation, steady-state inactivation, reversal potential, peak current, and refractory behavior were generated by the pClamp software and delivered to the Axoclamp 2-A amplifier via the TL-1 DMA interface. During these acquisition episodes, the membrane current was sampled at $20 \mathrm{kHz}$. Output bandwidth filter setting for the $3 \mathrm{db}$ cutoff frequency was $10 \mathrm{kHz}$.

PKA experiments. Most of the fish in this study had midrange EOD frequencies (sex not determined). To determine whether activation of the PKA pathway altered $\mathrm{Na}^{+}$channel properties in Sternopygus, the membrane-permeant cyclic adenosine monophosphate (cAMP) analog 8, bromo cAMP (8 Br cAMP) (Lot 73H7804, Sigma, St. Louis, MO) was used to activate PKA. The $8 \mathrm{Br}$ cAMP was dissolved in recording saline immediately before use at concentrations of $100 \mu \mathrm{M}, 1 \mathrm{~mm}$, or $5 \mathrm{~mm}$. After a good voltage clamp was achieved in regular recording saline, baseline recordings were made. The solution in the recording dish was then replaced by $\sim 10 \mathrm{ml}$ of additional saline (saline control), salinecontaining cAMP, or saline-containing $8 \mathrm{Br}$ cAMP. The solution changes required $\sim 6-8 \mathrm{~min}$ to complete. Immediately after the solution change, an initial recording in the new saline was made and was designated as time " 0 ." Subsequent recordings were made at 5 or 10 min intervals.

To confirm that the $8 \mathrm{Br}$ cAMP was acting via the PKA pathway, we added the PKA inhibitor H89 (lots 631393 and 827093, Calbiochem, La Jolla, CA) to the recording saline in the final set of experiments. H89 has been shown to be a potent and specific inhibitor of PKA (Chijiwa et al., 1990) which, when added to cell cultures at doses of 10-33 $\mu \mathrm{M}$, inhibits PKA specifically with no effect on responses evoked by stimulation of PKC (Chijiwa et al., 1990; Ginty et al., 1991; Geilen et al., 1992; Takuma and Ichida, 1994). The H89 was dissolved in 100\% dimethylsulfoxide (DMSO) and added to the recording saline at a final concentration of 30 $\mu \mathrm{M} \mathrm{H} 89$ and $1 \%$ DMSO. The tissue was pretreated with recording saline containing $30 \mu \mathrm{m} \mathrm{H} 89$ for at least $20 \mathrm{~min}$. At the end of the pretreatment period, a baseline recording was taken and then the saline was replaced with recording saline containing $1 \mathrm{~mm} 8 \mathrm{Br}$ cAMP, as well as $30 \mu \mathrm{M} \mathrm{H} 89$. Recording intervals were the same as in saline with $8 \mathrm{Br}$ cAMP alone. Controls had DMSO added to the recording saline to a final solution of $1 \%$.

\section{RESULTS}

\section{Effects of $8 \mathrm{Br}$ cAMP on voltage-dependent parameters of the Sternopygus $\mathrm{EO} \mathrm{Na}^{+}$current}

In many cells treated with $8 \mathrm{Br}$ cAMP, a slight increase in $\mathrm{Na}^{+}$ current magnitude could be seen at the earliest time recorded, i.e., as soon as we completed the solution change and began voltageclamp recording, defined as time " 0 ." By 20 min after the solution change to recording saline with $8 \mathrm{Br}$ cAMP, a marked increase in the $\mathrm{Na}^{+}$current magnitude was observed (Fig. 1). However, we observed no changes between $\mathrm{Na}^{+}$current inactivation kinetics $\left(\tau_{\mathrm{h}}\right)$ recorded in saline and those recorded in $8 \mathrm{Br}$ cAMP. In
A

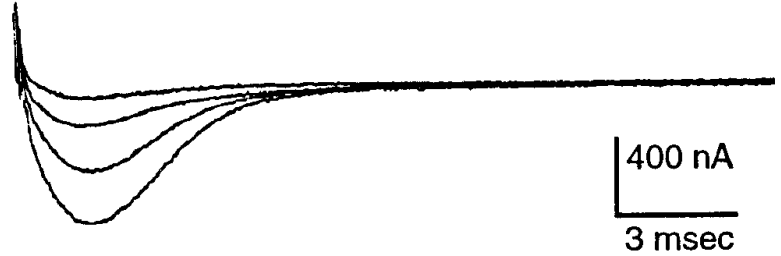

B

$\mathbf{B}$
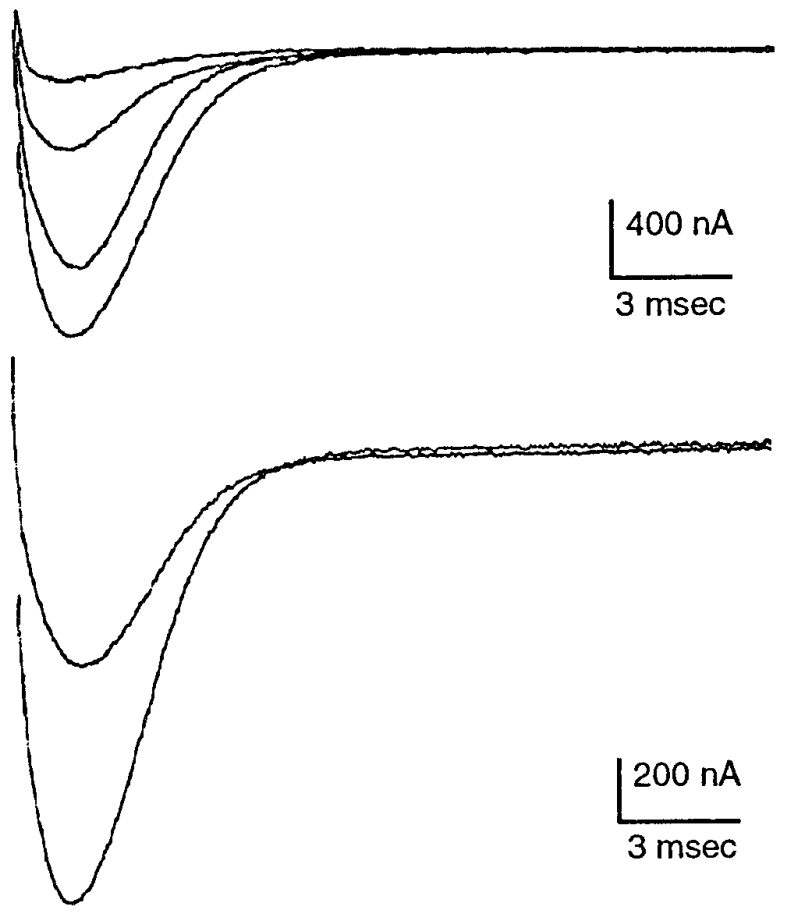

Figure 1. $\mathrm{Na}^{+}$currents at membrane potentials in steps of $10 \mathrm{mV}$ from -15 to $+15 \mathrm{mV}$ (peak current in this cell). $A$, Currents elicited in normal recording saline. $B$, Currents from the same cell elicited after $20 \mathrm{~min}$ exposure to $5 \mathrm{mM} 8 \mathrm{Br}$ cAMP. $C$, Peak currents from $A$ and $B$ superimposed.

control as well as $8 \mathrm{Br}$ cAMP-treated cells, we observed a slight transient decrease in $\tau_{\mathrm{h}}$ at time " 0 " followed by a slight gradual increase in $\tau_{\mathrm{h}}$ over the time course of the experiment. At $20 \mathrm{~min}$ after solution change, mean percent changes in $\tau_{\mathrm{h}}$ were: NaMS $1.375 \% \pm 14.463(\mathrm{SD}), n=4 ; 100 \mu \mathrm{M} 8 \mathrm{Br}$ cAMP $2.325 \pm 13.096$, $n=4 ; 1 \mathrm{~mm} 8 \mathrm{Br} 1.025 \% \pm 15.822, n=4$; and $5 \mathrm{~mm} 8 \mathrm{Br} 8.72 \%$ $\pm 7.435, n=5$.

Other voltage-dependent characteristics of the $\mathrm{Na}^{+}$current were not affected by treatment with $8 \mathrm{Br}$ cAMP (Fig. 2). There was a slight shift $(\sim 5 \mathrm{mV})$ in voltage of peak current in the hyperpolarizing direction, but this was seen at $20 \mathrm{~min}$ in the saline control group as well as in the experimental group (Fig. 2A,B). There were no differences between baseline and treatment in steady-state inactivation (Fig. $2 C, D$ ) or recovery from inactivation (Fig. $2 E, F$ ).

Steady-state membrane resistance increased slightly $(\sim 5 \%$ at $20 \mathrm{~min}$ ) over time in all groups (range for all treatment groups $2.378-8.916 \%$ ).

\section{Time course of PKA activation}

When we were able to hold the cell for sufficient time, current magnitude continued to increase through at least the first $30 \mathrm{~min}$ of recording and often was still increasing at $1 \mathrm{hr}$ (Fig. 3). In a few 

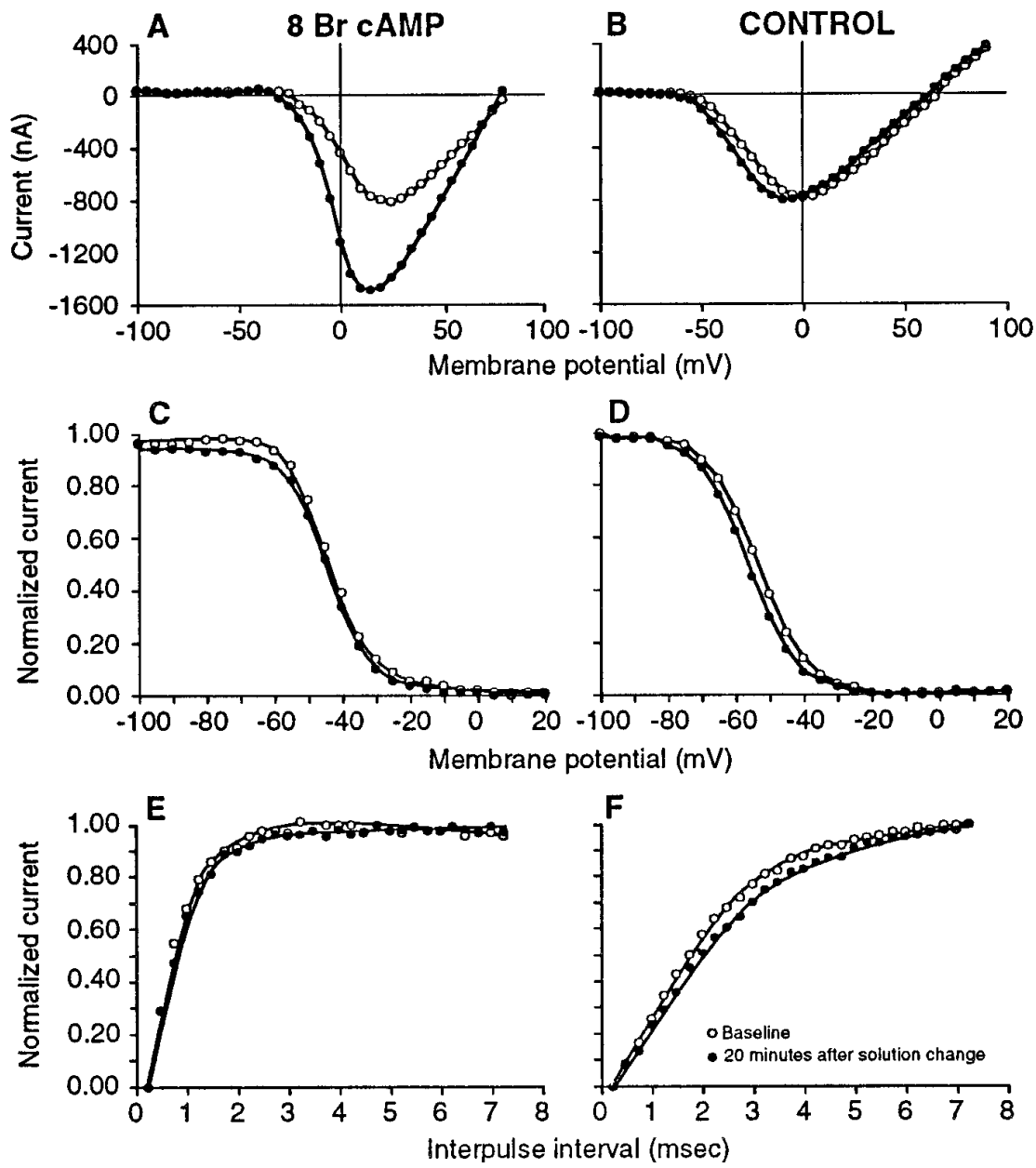

Figure 2. Treatment of electrocytes with $8 \mathrm{Br}$ cAMP does not alter voltage-dependent parameters of the $\mathrm{Na}^{+}$current. Open circles, Currents recorded in saline to obtain baseline values; closed circles, currents recorded $20 \mathrm{~min}$ after adding $5 \mathrm{~mm} 8 \operatorname{Br} \operatorname{cAMP}(A, C, E$ from the same cell in fish No. 553) or fresh saline (Controls $B, D, F$ from the same cell in fish No. 202). Current-voltage plots of representative cells illustrate that although voltage of peak current became slightly more hyperpolarized by $20 \mathrm{~min}$, this was a nonspecific effect seen in control $(B)$ as well as treated $(A)$ cells. In this case, the $\mathrm{Na}^{+}$current magnitude increased almost twofold in response to $8 \mathrm{Br}$ cAMP. No differences between baseline and either $8 \mathrm{Br}$ cAMP $(C)$ or control $(D)$ steady-state inactivation were seen (decrease in magnitude of $\mathrm{Na}^{+}$current to a standard test pulse at 0 $\mathrm{mV}$ caused by $25 \mathrm{msec}$ prepulses at the voltages indicated on the abscissa). Curves fit by Boltzmann equation. Recovery from inactivation before and after treatment with $5 \mathrm{~mm} 8 \mathrm{Br}$ cAMP $(E)$ or saline $(F)$ did not change from baseline [increase in magnitude of the $\mathrm{Na}^{+}$current to the second of two standard test pulses $(25 \mathrm{msec}, 0 \mathrm{mV})$ as the interval between them is increased]. Curves fit by eye. Differences in the slopes of curves between the cell from fish No. 202 illustrated in the right side of the figure $(B, D, F)$ and that from fish No. 553 on the left $(A, C, E)$ are indicative of the individual variation in these parameters between fish. cells, current plateaued or decreased slightly after $30 \mathrm{~min}$. However, in no cases did the magnitude return to baseline level. In contrast, in cells in recording saline alone, the $\mathrm{Na}^{+}$current often declined slightly over time.

We were reliably able to maintain a good voltage clamp for at least $20 \mathrm{~min}$. In addition, at least half of the total increase in current produced by $8 \mathrm{Br}$ cAMP occurred by $20 \mathrm{~min}$. Therefore,

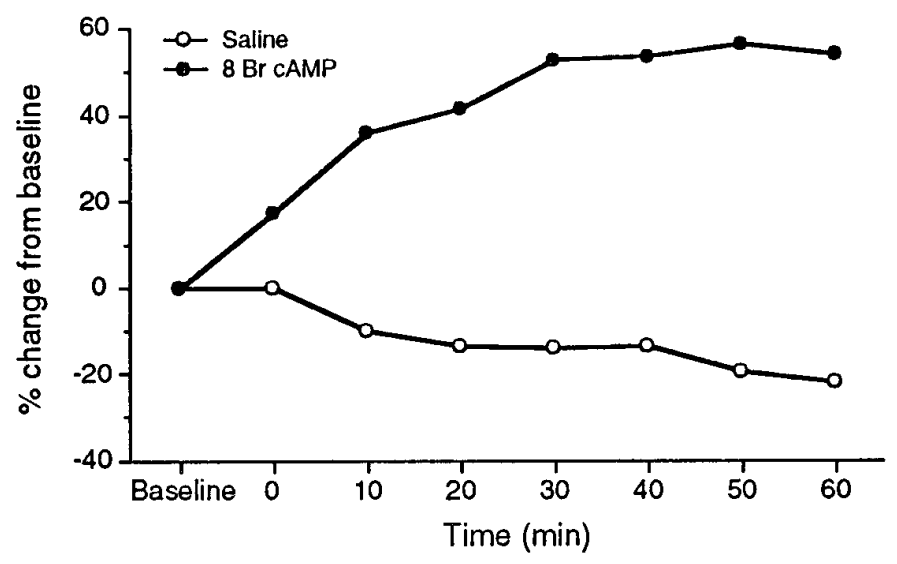

Figure 3. Time course of PKA activation in two representative cells. Closed circles, $1 \mathrm{~mm} 8 \mathrm{Br}$ cAMP; open circles, saline control. 8 Br cAMP produced a sustained increase in $\mathrm{Na}^{+}$current magnitude in contrast to a gradual decay in the current seen in controls. we used $20 \mathrm{~min}$ as a criterion time in further experiments to quantify the effect of $8 \mathrm{Br}$ cAMP.

\section{Dose-response of the effect of $8 \mathrm{Br}$ cAMP}

We examined the effect of $20 \mathrm{~min}$ exposure to $100 \mu \mathrm{M}, 1 \mathrm{mM}$, and $5 \mathrm{~mm} 8 \mathrm{Br}$ cAMP, as well as $1 \mathrm{~mm}$ cAMP, on the $\mathrm{Na}^{+}$current. All doses of $8 \mathrm{Br}$ cAMP produced increases in current magnitude that were significantly different from saline control at $p<0.05$ (Fig. 4, one-way ANOVA overall, $p=0.0001)$. The $\mathrm{Na}^{+}$current increase was dose-dependent, with a greater effect on the current magnitude at $1 \mathrm{~mm}($ mean $\pm \mathrm{SEM}=42.36 \pm 6.39 \%)$ than at $100 \mu \mathrm{M}$ $(17.64 \pm 1.64 \%)$. The effect plateaued at $1 \mathrm{~mm}$; there was no difference between 1 and $5 \mathrm{~mm}(43.06 \pm 8.06 \%)$. As noted previously, cells left in recording saline showed a decline in $\mathrm{Na}^{+}$ current over time. Cyclic AMP $(0.6 \pm 6.88 \%)$, which does not permeate the cell membrane as readily as $8 \mathrm{Br}$ cAMP, did not increase the current magnitude significantly compared with saline $(-16.8 \pm 5.41 \%)$, although it seemed to prevent the decline observed in saline.

\section{Effect of PKA inhibition}

To determine whether the effect we observed with cAMP analog treatment could be blocked specifically by PKA inhibition, we pretreated electrocytes in which a voltage clamp had been established (in regular recording saline) with $10 \mathrm{ml}$ of recording saline containing $30 \mu \mathrm{M} \mathrm{H} 89$ for at least $20 \mathrm{~min}$. New baseline recordings were made in this solution. We then replaced the H89 solution with $10 \mathrm{ml}$ of saline containing both $30 \mu \mathrm{M} \mathrm{H} 89$ and $1 \mathrm{~mm} 8 \mathrm{Br}$ 


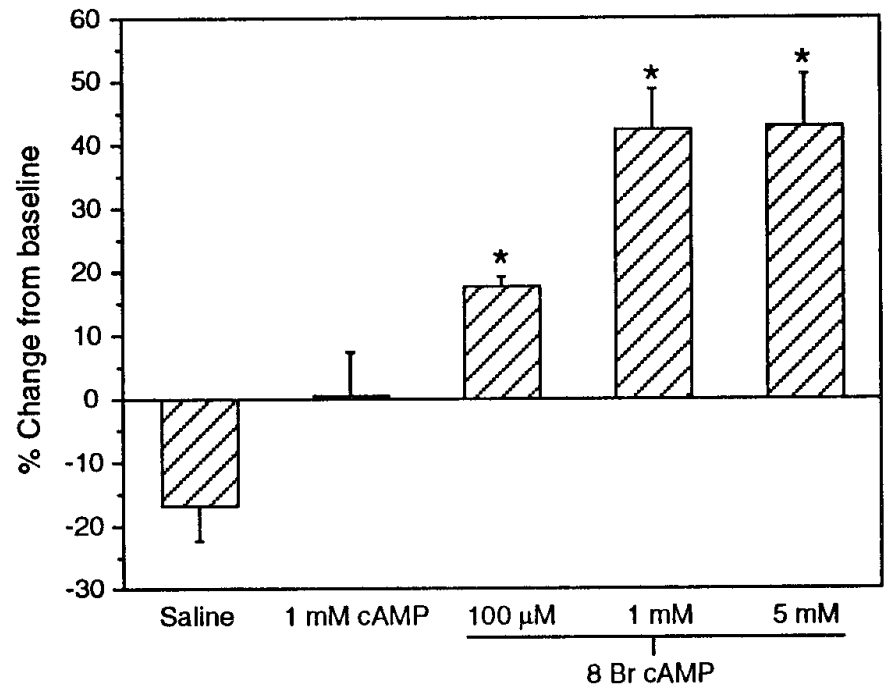

Treatment

Figure 4. Dose-response to $8 \mathrm{Br}$ cAMP. The enhancement of the $\mathrm{Na}^{+}$ current by $8 \mathrm{Br}$ cAMP was significantly different from saline at all doses tested (one-way ANOVA, overall $p=0.0001$, treatments different from each other at $p \leq 0.05$, Fisher protected least significant difference). Cyclic AMP was not significantly different from saline. $n=5$ in all treatments.

cAMP and examined voltage-clamp parameters as described in the previous experiment. In control experiments, DMSO was added to recording saline containing $1 \mathrm{~mm} 8 \mathrm{Br}$ cAMP at a final concentration of $1 \%$.

The effect of $8 \mathrm{Br}$ cAMP on $\mathrm{Na}^{+}$current magnitude was not influenced by DMSO, but was significantly blocked by treatment with $\mathrm{H} 89$ (Fig. 5). At 20 min, $\mathrm{Na}^{+}$current magnitude increased by an average of $36.36 \%( \pm 9.45 \%$ SEM $)$ in $8 \mathrm{Br}$ cAMP treated cells, but only by $8.42 \%( \pm 9.78)$ in cells also treated with H89. This difference was significant at $p=0.0173$ (unpaired two-tailed $t$

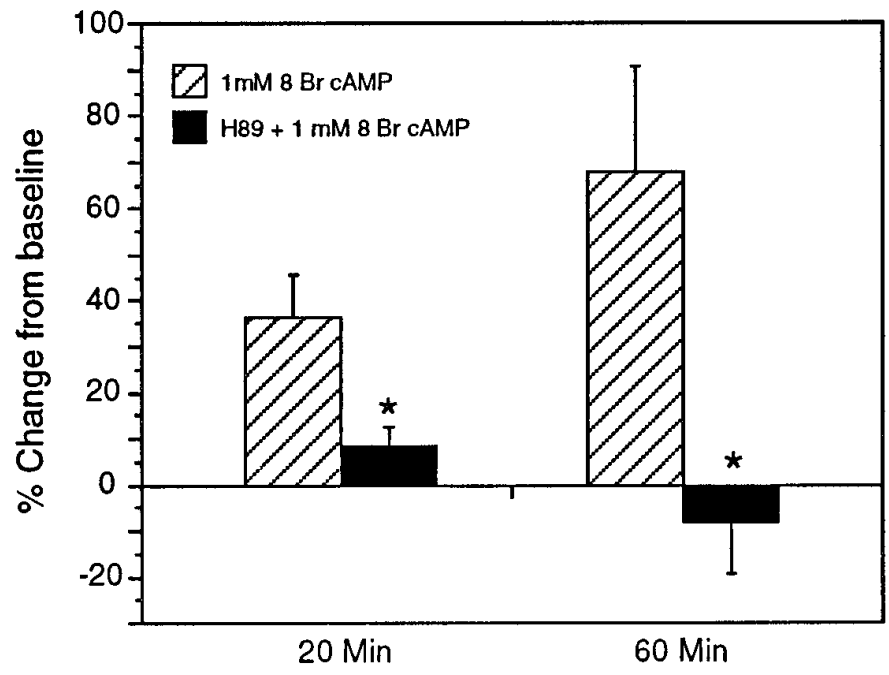

Figure 5. $\mathrm{H} 89(30 \mu \mathrm{M})$ blocked the effect of $1 \mathrm{~mm} 8 \mathrm{Br}$ cAMP on $\mathrm{Na}^{+}$ current magnitude. At 20 min, the $\mathrm{Na}^{+}$current in cells that had been preand cotreated with H89 $(n=6)$ was only $23 \%$ of that from cells treated with $8 \mathrm{Br}$ cAMP alone $(n=5)$. By $60 \mathrm{~min}$, the difference was even more pronounced because current magnitude continued to increase in cells treated with $8 \mathrm{Br}$ cAMP alone $(n=4$, one cell was lost before $60 \mathrm{~min})$ but declined relative to baseline values with $\mathrm{H} 89$ treatment $(n=5$, one cell was lost before $60 \mathrm{~min}$ ). test). By 60 min, whereas the $\mathrm{Na}^{+}$current magnitude continued to increase in $8 \mathrm{Br}$ cAMP-treated cells to $67.8 \%( \pm 22.88 \%)$ above baseline values, it had declined to $-8.06 \%$ ( $\pm 11.27 \%$ ) below baseline in those treated with H89 $(p=0.0154)$. $\mathrm{Na}^{+}$currents in cells treated with $\mathrm{H} 89$ alone declined slightly (an average of $11.6 \%$ by $20 \mathrm{~min}$ ). This was similar to cells in saline alone.

$\tau_{\mathrm{h}}$ was not significantly affected by $\mathrm{H} 89$; at $20 \mathrm{~min}$, mean percent change from baseline in $\tau_{\mathrm{h}}$ was $-2.367 \% \pm 12.099$ for 8 Br cAMP-treated cells $(n=6)$ and 3.8\% \pm 10.606 for cells treated with $\mathrm{H} 89+8 \mathrm{Br}$ cAMP $(n=5)$. Other voltage-dependent parameters were not significantly different between the two groups.

\section{DISCUSSION}

\section{Technical considerations}

We observed two nonspecific changes in the $\mathrm{Na}^{+}$current: a gradual decrease in current amplitude in cells exposed to saline only, and a slight shift in the hyperpolarizing direction of the voltage of peak current in saline as well as in $8 \mathrm{Br}$ cAMP-treated cells. These changes were not attributable to deterioration of the voltage clamp with a concomitant decrease in membrane resistance, because membrane resistance increased slightly on average in all groups, and we saw no indication that the clamp deteriorated. Nonspecific, time-dependent shifts in voltage-dependent parameters are observed in other systems (Grant and Wendt, 1992; Wendt et al., 1992; Ma et al., 1994).

The rundown that we observed in $\mathrm{Na}^{+}$current is also similar to that seen in other voltage-clamp studies of the $\mathrm{Na}^{+}$channel (Herzig and Kohlhardt, 1991; Smith and Goldin, 1992). In eel electrocytes, Shenkel and Sigworth (1991) observed a decrease of $\geq 95 \%$ in $\mathrm{Na}^{+}$currents recorded in excised patches from tissue that had been refrigerated overnight in normal saline. This effect was not observed in tissue stored in $\mathrm{Ca}^{2+}$-free saline, suggesting that an increase in intracellular $\mathrm{Ca}^{2+}$ may depress $\mathrm{Na}^{+}$currents.

\section{PKA mediates the cAMP-induced increase in $\mathrm{Na}^{+}$current}

We observed a significant increase in $\mathrm{Na}^{+}$current magnitude with the lowest concentration of $8 \mathrm{Br}$ cAMP used $(100 \mu \mathrm{M})$ and a saturation of the effect at 1-5 mM. We were able to block the effect of a saturating concentration of $8 \mathrm{Br}$ cAMP with the PKA inhibitor H89, supporting the hypothesis that the $8 \mathrm{Br}$ cAMP-induced $\mathrm{Na}^{+}$current increase was mediated by the PKA pathway.

The lack of an effect of cAMP and inhibition of the $8 \mathrm{Br}$ cAMP-induced increase in the $\mathrm{Na}^{+}$current by the PKA inhibitor H89 argue against an extracellular site of action as observed in cardiac myocytes (Sorbera and Morad, 1991), as well as a cyclic nucleotide-gated $\mathrm{Na}^{+}$channel (for review, see Zimmerman, 1995).

\section{Comparison with the effect of PKA on eel electrocytes and other cells}

The most closely related species in which phosphorylation of $\mathrm{Na}^{+}$ channels has been examined is the eel. Emerick et al. (1993) found that exposure of inside-out membrane patches from Sachs organ to PKA resulted in an $80 \%$ reduction in $\mathrm{Na}^{+}$current amplitude and a 10-12 $\mathrm{mV}$ negative shift in the current-voltage relation. These results are in apparent contradiction to our own. However, our studies differed in several aspects.

First, we used two-electrode voltage clamp of intact, nondissociated electrocytes in contrast to the eel study, in which excised patches were made from dissociated electrocytes. We did this to 
minimize any effects of dissociating enzymes on extracellular protein domains and the possible loss of cytoplasmic factors via dialysis and patch removal. In addition, any interactions between the $\mathrm{Na}^{+}$channel and cytoskeletal elements would be preserved in the intact electrocyte. Such interactions may influence channel function (Adelman, 1995).

Second, in the eel study phosphorylation was induced with an exogenous (bovine cardiac) PKA, whereas we presumably activated native PKA with $8 \mathrm{Br}$ cAMP. Although we did not directly determine that $8 \mathrm{Br}$ cAMP activates PKA, this is likely because the effect of $8 \mathrm{Br}$ cAMP is blocked by the addition of H89.

Third, although Sternopygus is a close relative of the electric eel, the differences in our results may be species differences. A comparison of the effect of PKA activation on $\mathrm{Na}^{+}$channels from each species under similar recording protocols would be instructive.

In other preparations, PKA-dependent phosphorylation of voltage-dependent $\mathrm{Na}^{+}$channels is generally reported to decrease current amplitude (Gershon et al., 1992; Grant and Wendt, 1992; Li et al., 1992; Li et al., 1993; Schiffmann et al., 1995). However, current increases have been reported in other studies of similar channels (Smith and Goldin, 1992; Matsuda et al., 1992). The control of channel properties by phosphorylation is complex and depends on many factors. For example, phosphorylation of certain sites can alter the effect of subsequent phosphorylation at other sites. Previous PKC phosphorylation is required for PKA to decrease the current of rat brain IIA $\mathrm{Na}^{+}$channels expressed in Chinese hamster ovary cells, whereas PKA activation alone either has no affect or increases $\mathrm{Na}^{+}$currents (Li et al., 1993). We do not yet know the extent to which the Sternopygus $\mathrm{Na}^{+}$channel is endogenously phosphorylated.

\section{Possible mechanisms of the cAMP effect on electrocyte $\mathrm{Na}^{+}$currents}

The most straightforward explanation of our results is that PKA phosphorylates the $\mathrm{Na}^{+}$channel directly, increasing the probability of channel opening. Nevertheless, PKA could affect $\mathrm{Na}^{+}$ current amplitude by acting on other substrates. For example, PKA could phosphorylate a regulatory subunit associated with the $\mathrm{Na}^{+}$channel. $\beta$ subunits, for example, are well known in mammalian tissues, although they do not appear to be phosphorylated by PKA (Hartshorne and Catterall, 1984; Yang et al., 1993). In addition, attempts to identify $\beta$ subunits in eel or Sternopygus electrocytes have thus far been unsuccessful (Correa et al., 1990; Isom et al., 1992; Lopreato, personal communication).

Rather than acting on channels already in the membrane, cAMP activation could increase current amplitude by inducing synthesis of new $\mathrm{Na}^{+}$channels as has been observed in other systems (Sherman and Catterall, 1984; Offord and Catterall, 1989; Zhang et al., 1992). However, sodium channels are large, heavily glycosylated proteins; in eel electrocytes, it takes $8-24 \mathrm{hr}$ for new $\mathrm{Na}^{+}$channels to be transcribed, translated, and post-translationally processed (Thornhill and Levinson, 1987). Because we observed increases in current magnitude within minutes of the addition of $8 \mathrm{Br}$ cAMP, it is unlikely that the mechanism requires transcription of $\mathrm{Na}^{+}$channel genes.

Another possibility is that PKA phosphorylates a cytoskeletal or vesicular protein that induces the incorporation of mature $\mathrm{Na}^{+}$ channels from a cytoplasmic reservoir. For example, recent reports suggest that vasopressin acts via PKA to insert new amiloride-sensitive $\mathrm{Na}^{+}$channels into the cell membrane within 5 min to an hour (Marunaka and Eaton, 1991; Kleyman et al.,
1994). The time course of the $\mathrm{Na}^{+}$current increase that we observed in Sternopygus is also consistent with this mechanism.

\section{Physiological and behavioral significance}

Assuming there is no compensating change in other ion currents, an increase in $\mathrm{Na}^{+}$current amplitude would result in an increase in AP amplitude and the current generated by the EO. This, in turn, would increase the amplitude of the EOD around the fish.

Behaviorally relevant variation in EOD amplitude occurs in various species of electric fish. EOD amplitude varies diurnally (Franchina, 1993; Hagedorn, 1995) and is increased rapidly in response to physical stimulation or social interactions in some gymnotiforms (Hagedorn and Zelick, 1989; Hagedorn, 1995). EOD amplitude also responds to changes in water conductivity. Because the mormyrid EO acts like a constant current source (Bell et al., 1976), changes in water conductance result in changes in EOD voltage. Kuhn and Kramer (1993) have shown that although EOD amplitude drops after mormyrid fish are placed in highly conductive water, compensatory increases in EOD amplitude (presumably attributable to increased current output of the EO) occur over the next few days. When fish are returned to higher resistance water, EOD amplitude is anomolously high for a few days and then returns to baseline. One mechanism for increasing the current output of the EO would be an increase in $\mathrm{Na}^{+}$current.

A more detailed understanding of the endocrinological changes associated with changes in EOD amplitude might point to a hormone responsible for initiating the cAMP cascade. Considering the EOD response to changes in water conductivity, for example, changes in prolactin (an osmoregulatory hormone in fish) levels during altered osmoregulatory loads could affect PKA activation, upregulate $\mathrm{Na}^{+}$currents, and thereby increase current output of the EO. Changes in EO amplitude that occur during courtship (Hagedorn and Heiligenberg, 1985) might be a result of hormones, such as the peptide arginine vasotocin, which is known to be increased during courtship in lower vertebrates (Moore, 1992).

Although we have previously shown that androgens modulate $\mathrm{Na}^{+}$current kinetics in Sternopygus (Ferrari et al., 1995), it is unlikely that this is mediated by the PKA-dependent changes that we observed in this study. Changes in AP duration were observed only after the fish had been exposed to DHT for a week (Mills and Zakon, 1987), whereas we observed increased $\mathrm{Na}^{+}$current amplitude within minutes of exposure to $8 \mathrm{Br}$ cAMP. In addition, we observed no effect of $8 \mathrm{Br}$ cAMP on $\mathrm{Na}^{+}$current kinetics. However, if there are multiple phosphorylation sites in the Sternopygus $\mathrm{Na}^{+}$channel that are differentially phosphorylated by different kinases such as $\mathrm{PKC}$, it is still possible that phosphorylation modulates current kinetics. We plan to examine the effect of PKC activators on the Sternopygus $\mathrm{Na}^{+}$channel in the future. Because, as noted above, the level of endogenous phosphorylation can affect the response obtained by activation of protein kinases, we plan to determine the level of endogenous phosphorylation of electrocyte $\mathrm{Na}^{+}$channels and to examine the effect of protein phosphatases on these channels.

\section{REFERENCES}

Adelman JP (1995) Proteins that interact with the pore-forming subunits of voltage-gated ion channels. Curr Opin Neurobiol 5:286-295.

Bell CC, Bradbury J, Russell CJ (1976) The electric organ of a mormyrid as a current and voltage source. J Comp Physiol 110: 65-88.

Bennett MVL (1961) Modes of operation of electric organs. Ann NY Acad Sci 54:458-494. 
Bennett MVL (1971) Electric organs. In: Fish physiology (Hoar WS, Randall DJ, eds) pp 347-492. New York: Academic.

Bullock TH, Heiligenberg W (1986) Electroreception. New York: Wiley.

Chijiwa T, Mishima A, Hagiwara M, Sano M, Hayashi K, Tsutomu I, Naito K, Toshioka T, Hidaka H (1990) Inhibition of forskolin-induced neurite outgrowth and protein phosphorylation by a newly synthesized selective inhibitor of cyclic AMP-dependent protein kinase, $\mathrm{N}$-[2-(pbromocinnamylamino)ethyl]-5-isoquinolinesulfonamide (H-89), of PC 12D pheochromocytoma cells. J Biol Chem 265:5267-5272.

Correa AM, Bezanilla F, Agnew WS (1990) Voltage activation of purified eel sodium channels reconstituted into artificial liposomes. Biochemistry 29:6230-6240.

Elliott AA, Elliott JR (1993) Characterization of TTX-sensitive and TTX-resistant sodium currents in small cells from adult rat dorsal root ganglia. J Physiol (Lond) 463:39-56.

Emerick MC, Agnew WS (1989) Identification of phosphorylation sites for adenosine $3^{\prime}, 5^{\prime}$-cyclic phosphate dependent protein kinase on the voltage-sensitive sodium channel from Electrophorus electricus. Biochemistry $28: 8367-8380$

Emerick MC, Shenkel S, Agnew WS (1993) Regulation of the eel electroplax Na channel and phosphorylation of residues on amino- and carboxyl-terminal domains by cAMP-dependent protein kinase. Biochemistry 32:9435-9444.

Ferrari MB, Zakon HH (1993) Conductances contributing to the action potential of Sternopygus electrocytes. J Comp Physiol [A] 173:281-292.

Ferrari MB, McAnelly ML, Zakon HH (1995) Individual variation in and androgen-modulation of the sodium current in electric organ. J Neurosci $15: 4023-4032$

Franchina CR (1993) The waveform of the weakly electric fish Hypopomus pinnicaudatus changes daily in the male. J Comp Physiol [A] 173:742.

Geilen CG, Wieprecht M, Wieder T, Reutter W (1992) A selective inhibitor of cyclic AMP-dependent protein kinase, $N$-[2-(pbromocinnamylamino)ethyl]-5-isoquinolinesulfonamide (H-89), inhibits phosphatidylcholine biosynthesis in HeLa cells. FEBS Lett 309:381-384.

Ginty DD, Glowacka D, Bader DS, Hidaka H, Wagner J A (1991) Induction of immediate early genes by $\mathrm{Ca}^{2+}$ requires cAMP-dependent protein kinase in PC12 cells. J Biol Chem 266:17454-17458.

Gershon E, Weigl L, Lotan I, Schreibmayer W, Dascal N (1992) Protein kinase A reduces voltage-dependent $\mathrm{Na}^{+}$current in Xenopus oocytes. J Neurosci 12:3743-3752.

Grant AO, Wendt DJ (1992) Block and modulation of cardiac $\mathrm{Na}^{+}$ channels by antiarrhythmic drugs, neurotransmitters and hormones. Trends Pharmacol Sci 13:352-358.

Hagedorn M (1995) The electric fish Hypopomus occidentalis can rapidly modulate the amplitude and duration of its electric organ discharges. Anim Behav 49:1409-1413.

Hagedorn M, Heiligenberg W (1985) Court and spark: electric signals in the courtship and mating of gymnotoid electric fish. Anim Behav 33:254-265.

Hagedorn M, Zelick R (1989) Relative dominance among males is expressed in the electric organ discharge characteristics of a weakly electric fish. Anim Behav 38:520-525.

Hartshorne RP, Catterall WA (1984) The sodium channel from rat brain: purification and subunit composition. J Biol Chem 259:1667-1675

Herzig J, Kohlhardt M (1991) $\mathrm{Na}^{+}$channel blockade by cyclic AMP and other 6-aminopurines in neonatal rat heart. J Membr Biology 119:163-170.

Hille B (1992) Ionic channels of excitable membranes. 2nd Ed. Sunderland, MA: Sinauer.

Hopkins CD (1972) Sex differences in electric signaling in an electric fish. Science 176:1035-1037.

Hopkins CD (1974) Electric communication in the reproductive behavior of Sternopygus macrurus (Gymnotidae). Z Tierpsychol 35:518-535.

Isom LL, De Jongh KS, Patton DE, Reber BFX, Offord J, Charbonneau H, Walsh K, Goldin AL, Catterall WA (1992) Primary structure and functional expression of the $\beta_{1}$ subunit of the rat brain sodium channel. Science 256:839-842.

Kallen RG, Shen ZH, Yang J, Chen L, Rogart RB, Barchi RL (1990) Primary structure and expression of a sodium channel characteristic of denervated and immature rat skeletal muscle. Neuron 4:233-242.

Kleyman T, Ernst S, Coupaye-Gerard B (1994) Arginine vasopressin and forskolin regulate apical cell surface expression of epithelial $\mathrm{Na}^{+}$channels in A6 cells. Am J Physiol 266:F506-F511.
Kuhn B, Kramer B (1993) Constancy of communication and orientation signal of weakly electric fishes (Mormyridae) during changing water conductivity. J Comp Physiol [A] 173:740.

Li M, West J, Lai Y, Scheuer T, Catterall W (1992) Functional modulation of brain sodium channels by cAMP-dependent phosphorylation. Neuron 8:1151-1159.

Li M, West JW, Numann R, Murphy BJ, Scheuer T, Catterall WA (1993) Convergent regulation of sodium channels by protein kinase $\mathrm{C}$ and cAMP-dependent protein kinase. Science 261:1439-1442.

Ma J, Catterall W, Scheuer T (1994) Modulation of brain $\mathrm{Na}^{+}$channels by a G-protein-coupled pathway. Proc Natl Acad Sci USA 91:12351-12355.

Marunaka Y, Eaton DC (1991) Effects of vasopressin and cAMP on single amiloride-blockable Na channels. Am J Physiol 260:C1071-C1084.

Matsuda J, Lee H, Shibata E (1992) Enhancement of rabbit cardiac sodium channels by beta-adrenergic stimulation. Circ Res 70:199-207.

Meyer JH (1983) Steroid influeces upon the discharge frequency of a weakly electric fish. J Comp Physiol [A] 153:29-38.

Mills AC, Zakon HH (1987) Coordination of EOD frequency and pulse duration in a weakly electric wave fish: the influence of androgens. J Comp Physiol [A] 161:417-430.

Mills AC, Zakon HH (1991) Chronic androgen treatment increases action potential duration in the electric organ of Sternopygus. J Neurosci 11:2349-2361.

Moore FL (1992) Evolutionary precedents for behavioral actions of oxytocin and vasopressin. Ann NY Acad Sci 652:156-165.

Numann R, Catterall WA, Scheuer T (1991) Functional modulation of brain sodium channels by protein kinase $\mathrm{C}$ phosphorylation. Science 254:115-118.

Offord J, Catterall W (1989) Electrical activity, cAMP, and cytosolic calcium regulate mRNA encoding sodium channel A subunits in rat muscle cells. Neuron 2:1447-1452.

Ogata N, Tatebayashi $\mathrm{H}$ (1993) Kinetic analysis of two types of $\mathrm{Na}^{+}$ channels in rat dorsal root ganglia. J Physiol (Lond) 466:9-37.

Rizzo MA, Kocsis JD, Waxman SG (1994) Slow sodium conductances of dorsal root ganglion neurons: intraneuronal homogeneity and interneuronal heterogeneity. J Neurophysiol 72:2796-2815.

Schiffmann S, Lledo P, Vincent J (1995) Dopamine D1 receptor modulates the voltage-gated sodium current in rat striatal neurones through a protein kinase A. J Physiol (Lond) 483:95-107.

Shenkel S, Sigworth SF (1991) Patch recordings from the electrocytes of Electrophorus electricus. Na current and $\mathrm{PNa} / \mathrm{Pk}$ variability. J Gen Physiol 97:1013-1041.

Sherman S, Catterall W (1984) Electrical activity and cytosolic calcium regulate levels of tetrodotoxin-sensitive sodium channels in cultured rat muscle cells. Proc Natl Acad Sci USA 81:262-266.

Smith RD, Goldin AL (1992) Protein kinase A phosphorylation enhances sodium channel currents in Xenopus oocytes. Am J Physiol 263:C660-C666.

Sorbera L, Morad M (1991) Modulation of cardiac sodium channels by cAMP receptors on the myocyte surface. Science 253:1286-1289.

Takuma T, Ichida T (1994) Evidence for the involvement of protein phosphorylation in cyclic AMP-mediated amylase exocytosis from parotid acinar cells. FEBS Lett 340:29-33.

Thornhill W, Levinson S (1987) Biosynthesis of electroplax sodium channels in Electrophorus electrocytes and Xenopus oocytes. Biochemistry 26:4381-4388.

Wendt DJ, Starmer CF, Grant AO (1992) Na channel kinetics remain stable during perforated-patch recordings. Am J Physiol 263:C1234-C1240.

Yang J, Bennett P, Makita N, George A, Barchi R (1993) Expression of the sodium channel $\beta_{1}$ subunit in rat skeletal muscle is selectively associated with the tetrodotoxin-sensitive $\alpha$ subunit isoform. Neuron 11:915-922.

Zakon HH, Thomas P, Yan HY (1991) Electric organ discharge frequency and plasma sex steroid levels during gonadal recrudescence in a natural population of the weakly electric fish Sternopygus macrurus. J Comp Physiol [A] 169:493-499.

Zhang J, Robinson R, Siegelbaum S (1992) Sympathetic neurons mediate developmental change in cardiac sodium channel gating through long-term neurotransmitter action. Neuron 9:97-103.

Zimmerman A (1995) Cyclic nucleotide gated channels. Curr Opin Neurobiol 5:296-303. 